\title{
Effect of reoxygenation and Marenzelleria spp. bioturbation on Baltic Sea sediment metabolism
}

\author{
S. Bonaglia' ${ }^{1, *}$, M. Bartoli ${ }^{2}$, J. S. Gunnarsson ${ }^{3}$, L. Rahm ${ }^{4}$, C. Raymond ${ }^{3}$, O. Svensson ${ }^{3}$, \\ S. Shakeri Yekta ${ }^{4}$, V. Brüchert ${ }^{1}$ \\ ${ }^{1}$ Department of Geological Sciences, and ${ }^{3}$ Department of Systems Ecology, Stockholm University, 10691 Stockholm, Sweden \\ ${ }^{2}$ Department of Environmental Sciences, University of Parma, 43124 Parma, Italy \\ ${ }^{4}$ Department of Thematic Studies - Water and Environment, Linköping University, 58183 Linköping, Sweden
}

\begin{abstract}
Nutrient reduction and the improvement of bottom water oxygen concentrations are thought to be key factors in the recovery of eutrophic aquatic ecosystems. The effects of reoxygenation and bioturbation of natural hypoxic sediments in the Baltic Sea were studied using a mesocosm experiment. Anoxic sediment box cores were collected from $100 \mathrm{~m}$ depth in Kanholmsfjärden (Stockholm Archipelago) and maintained in flow-through mesocosms with 3 treatments: (1) hypoxic: supplied with hypoxic water; (2) normoxic: supplied with oxic water; and (3) Marenzelleria: supplied with oxic water and the polychaete Marenzelleria spp. (2000 ind. $\mathrm{m}^{-2}$ ). After a $7 \mathrm{wk}$ long conditioning period, net fluxes of dissolved $\mathrm{O}_{2}, \mathrm{CH}_{4}, \mathrm{Fe}^{2+}, \mathrm{Mn}^{2+}, \mathrm{NH}_{4}{ }^{+}, \mathrm{NO}_{2}^{-}, \mathrm{NO}_{3}{ }^{-}$, $\mathrm{PO}_{4}{ }^{3-}$ and $\mathrm{H}_{4} \mathrm{SiO}_{4}$, and rates of nitrate ammonification (DNRA), denitrification and anammox were determined. Phosphate was taken up by the sediment in all treatments, and the uptake was highest in the normoxic treatment with Marenzelleria. Normoxic conditions stimulated the denitrification rate by a factor of 5 . Denitrification efficiency was highest under normoxia (50\%), intermediate in bioturbated sediments (16\%), and very low in hypoxic sediments $(4 \%)$. The shift from hypoxic to normoxic conditions resulted in a significantly higher retention of $\mathrm{NH}_{4}{ }^{+}, \mathrm{H}_{4} \mathrm{SiO}_{4}$ and $\mathrm{Mn}^{2+}$ in the sediment, but the bioturbation by Marenzelleria reversed this effect. Results from our study suggest that bioturbation by Marenzelleria stimulates the exchange of solutes between sediment and bottom water through irrigation and enhances bacterial sulfate reduction in the burrow walls. The latter may have a toxic effect on nitrifying bacteria, which, in turn, suppresses denitrification rates.
\end{abstract}

KEY WORDS: Hypoxia $\cdot$ Macrofauna $\cdot$ Mesocosm $\cdot$ Denitrification $\cdot$ Dissimilatory nitrate reduction to ammonium $\cdot$ DNRA $\cdot$ Benthic Flux $\cdot$ Baltic Sea

\section{INTRODUCTION}

Large zones with anoxic or hypoxic sediments are common in many eutrophic coastal areas with stratified waters or low water circulation (Rabalais et al. 2010). Hypoxia $\left(\mathrm{O}_{2}<60 \mu \mathrm{M}\right)$ can be transient and local, with minor consequences at the ecosystem level, but it can also persist for long periods over large areas and can alter the structure of aquatic communities and energy transfer processes (Diaz \&
Rosenberg 2008). Vast areas of the Baltic Sea suffer from bottom water hypoxia, mainly due to cultural eutrophication, the long residence time and thermohaline stratification of water masses (Conley et al. 2009). In sediments under hypoxic waters faunal aerobic respiration processes are suppressed and anaerobic mineralization pathways of organic carbon such as bacterial sulfate reduction, methanogenesis, and reduction of manganese and iron oxyhydroxides prevail. The dominance of anaerobic bacterial pro- 
cesses also profoundly alters the pathways and stoichiometry of nutrient cycling. For example, the lack of oxygen and high concentrations of sulfide inhibit nitrification within the sediment (Burgin \& Hamilton 2007), suppressing denitrification rates and resulting in low $\mathrm{N}_{2}$ loss rates. High iron reduction rates and the formation of iron sulfides, in turn, stimulate the phosphate loss from anoxic sediments (Reed et al. 2011). Changes in benthic oxygenation therefore not only alter rates and pathways of carbon mineralization, but also change the rates and stoichiometry of recycled nitrogen and phosphorus, which can have significant implications for primary producer communities and contribute to shifts from calcareous or diatom-dominated to cyanobacterial bloom-dominated primary production (Elmgren 2001, Vahtera et al. 2007).

Bottom water hypoxia or anoxia affect the macrofaunal community and reduce sediment bioirrigation and bioturbation (Gray et al. 2002, Karlson et al. 2002, Glud 2008, Gambi et al. 2009). The bioturbation activities of benthic macrofauna, i.e. the biological mixing and transport of particles and solutes in the upper sediment layer, are known to profoundly affect essential ecosystem functions of benthic ecosystems, including biogeochemical cycling, carbon storage and various chemical and microbial processes, as well as physical characteristics such as porosity and sediment surface topography (Kristensen et al. 1992, Aller \& Aller 1998, Schiffers et al. 2011). Bioirrigating benthic macrofauna enhance the oxygenation of sediments and increase the availability of electron acceptors such as oxygen, $\mathrm{NO}_{3}{ }^{-}, \mathrm{Mn}$ and $\mathrm{Fe}$ oxides. Bioturbation also leads to a more efficient decomposition of buried organic matter, which renders refractory organic matter more labile and decreases the rates of anaerobic carbon mineralization processes (Kristensen \& Kostka 2005). In many sediments of the Baltic Sea the abundance of burrowing macrofauna has decreased as a consequence of spreading hypoxia and sulfidic conditions (Gray et al. 2002). During the last 2 decades, however, invading polychaete species of the genus Marenzelleria have colonized large sediment areas of the Baltic Sea, at densities ranging from several 100 to several 1000 ind. $\mathrm{m}^{-2}$, making it one of the dominating macrofaunal species of the Baltic Sea (Zettler et al. 2002).

The new Marenzelleria spp. consist of 3 morphologically similar coexisting sibling species only distinguisable using genetic tools (Blank et al. 2008) The ecology and bioturbation mode of the 3 species are still largely unknown. Recent studies have, however, shown that Marenzelleria spp. is able to dig deep burrows down to ca. $20 \mathrm{~cm}$ depth (Zettler et al. 1995) and that they are highly efficient bioirrigators (Hedman et al. 2011, Kristensen et al. 2011). Based on modeling data, Norkko et al. (2012) suggested that the colonization of the Baltic Sea sediment by Marenzelleria spp. could improve the quality of the benthic system through enhanced oxygenation and phosphorus retention in the sediment and thus counteract eutrophication.

We collected intact sediment box cores from a $100 \mathrm{~m}$ anoxic fjord within the Stockholm archipelago and carried out a long-term mesocosm experiment in order to examine the effects of (1) reoxygenation from hypoxic ( $<60 \mu \mathrm{M}$ dissolved oxygen) to normoxic conditions ( $300 \mu \mathrm{M}$ dissolved oxygen) and (2) bioturbation by the polychaete Marenzelleria spp. on biogeochemical processes and benthic nutrient fluxes.

\section{MATERIALS AND METHODS}

\section{Setup of mesocosms}

Sediments (12 box cores, $20 \times 20 \times 30 \mathrm{~cm}$ high) were collected on June 7, 2011 at 105 m depth in Kanholmsfjärden (Stockholm archipelago, 59²0.1814' N, $018^{\circ} 46.2680^{\prime} \mathrm{E}$ ), using a Jonasson-Olausson box corer (Fig. 1). Kanholmsfjärden has year-round anoxic or hypoxic bottom waters, and the sediment is typically black and sulfidic, with a porosity of 0.9 . Total carbon content (mmol g ${ }^{-1}$ dry weight) and molar $\mathrm{C} / \mathrm{N}$ ratios of Kanholmsfjärden sediment in June 2011 were 5.7 and 9.7 from 0 to $3 \mathrm{~cm}$ depth, 5.6 and 10.6 from 3 to $6 \mathrm{~cm}, 5.1$ and 10.0 from 6 to $10 \mathrm{~cm}$, respectively (Ekeroth et al. unpubl. data). Bottom water was collected using a modified Niskin water sampler to measure temperature $\left(4.7^{\circ} \mathrm{C}\right)$, salinity (8) and dissolved oxygen $(<5 \mu \mathrm{M})$ using a digital multi-meter and the Winkler method for the latter. On board, sediments from each box core were transferred to Plexiglas mesocosms $(20 \times 20 \times 50 \mathrm{~cm}$ high $)$ and sealed with a bottom and a lid. The mesocosms were transported to the Askö Laboratory, Stockholm University Marine Research Center, filled to the top with hypoxic seawater and left for acclimatization during $48 \mathrm{~d}$ in a dark climate room at $5^{\circ} \mathrm{C}$. The water column of the mesocosms was kept hypoxic (ca. $20 \mu \mathrm{M}$ ) during the whole conditioning phase.

After the conditioning phase, the mesocosms were immersed in a water bath with circulating, natural seawater to keep the temperature constant at $5^{\circ} \mathrm{C}$. The mesocosms were then connected to peristaltic pumps and continuously circulated (ca. $15 \mathrm{ml} \mathrm{min}^{-1}$ ) 


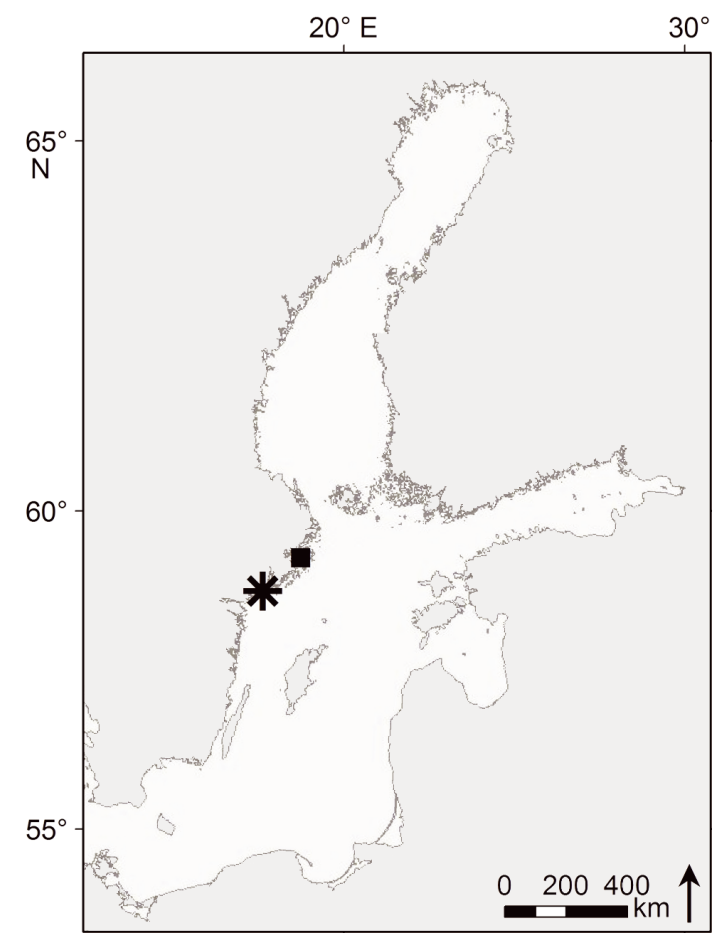

Fig. 1. The Baltic Sea, showing where the box cores and Marenzelleria spp. were collected ( $\mathbf{\square})$, and the location of Stockholm University Marine Research Center at Askö, where the experiment was performed $(*)$

with sand-filtered natural seawater pumped from $20 \mathrm{~m}$ depth. Of the mesocosms, 8 were supplied with oxic $\left(\sim 300 \mu \mathrm{M} \mathrm{O} \mathrm{O}_{2}\right)$ and 4 with hypoxic seawater $\left(\sim 50 \mu \mathrm{M} \mathrm{O}_{2}\right)$. The seawater was first circulated into 3 water towers (1.8 $\mathrm{m}$ high, $30 \mathrm{~cm}$ inner diameter). Of the towers, 1 was used to supply the mesocosms with oxic and the other 2, connected in series, were used to supply the mesocosms with hypoxic seawater. Hypoxic $\mathrm{O}_{2}$ concentrations were maintained by bubbling the incoming tower with $\mathrm{N}_{2}$. The $\mathrm{O}_{2}$ concentration was kept constant by using an optical $\mathrm{O}_{2}$ sensor (dTRANS O2 01, JUMO) in the outgoing tower, connected to a digital unit that regulated the amount of $\mathrm{N}_{2}$ bubbling in the incoming tower. The water inside all mesocosms was mixed by magnetic stirrers at $60 \mathrm{rpm}$. The mesocosms were supplied in flow-through conditions with either oxic $(n=8)$ or hypoxic water ( $n=4$ ) over $26 \mathrm{~d}$, in order to start the reoxygenation of the surface sediment, after which 80 ind. of Marenzelleria spp., corresponding to a density of 2000 ind. $\mathrm{m}^{-2}$ were added to 4 of the oxic mesocosms. The polychaetes were collected on September 9, 2011 in Kanholmsfjärden $\left(59^{\circ} 20.3701^{\prime} \mathrm{N}, 018^{\circ} 45.3815^{\prime} \mathrm{E}\right)$ near the location where the box cores were taken, but in oxic waters at a shallower depth (55 m; Fig. 1). Following addition of the polychaetes, the mesocosms were kept in flow-through conditions for another $48 \mathrm{~d}$ until the end of the experiment. In total, the experiment included 3 different treatments with 4 replicate mesocosms each: (1) hypoxic water (HY), (2) normoxic water (NO) and (3) normoxic and bioturbated, i.e. normoxic with Marenzelleria spp. (NOB).

\section{Collection of intact sediment cores from mesocosms and flux measurements}

After $48 \mathrm{~d}$, sediments from each mesocosm were subsampled by inserting Plexiglas tubes $(25 \mathrm{~cm}$ length, $3.6 \mathrm{~cm}$ inner diameter, $\mathrm{n}=3$ ) in each mesocosm. The cores were capped with rubber stoppers, gently extracted and then capped below. A total of 36 cores (12 replicates for each treatment) were collected; all cores were adjusted to contain $12 \mathrm{~cm}$ of sediment and $10 \mathrm{~cm}$ of water phase. Cores from the same treatment were then transferred to a temperature-controlled room at $5^{\circ} \mathrm{C}$ and placed in incubation buckets containing water taken from each respective mesocosm. The cores were submerged, the top cap was removed and stirrer bars, driven by an external magnet at $60 \mathrm{rpm}$, were inserted to the water phase of each core. The cores were then maintained for $6 \mathrm{~h}$ before the incubation started. Water in the buckets containing the NO and NOB cores was bubbled with air and mixed with aquarium pumps, while the bucket with HY cores was bubbled with a mixture of air and $\mathrm{N}_{2}$, maintaining an $\mathrm{O}_{2}$ concentration of $\sim 50 \mu \mathrm{M}$.

At the beginning of the incubation, water samples (ca. $50 \mathrm{ml}$ ) were collected from the buckets $(\mathrm{n}=5$ for each tank) with plastic syringes, and all cores were closed with rubber stoppers and stirred. An incubation period of $8 \mathrm{~h}$ was selected in order to keep the final $\mathrm{O}_{2}$ concentration to within $20 \%$ of the initial value. At the end of the incubation an additional water sample (ca. $50 \mathrm{ml}$ ) was collected from each core. Immediately after water sampling, 1 aliquot was transferred to $7.7 \mathrm{ml}$ Exetainers (Labco Scientific) and poisoned with $50 \mu \mathrm{l}$ of $7 \mathrm{M} \mathrm{ZnCl}_{2}$ for $\mathrm{CH}_{4}$ analysis; 1 aliquot was filtered (GF/F glass-fiber filters) and stored in plastic vials for dissolved $\mathrm{NH}_{4}{ }^{+}, \mathrm{NO}_{3}{ }^{-}, \mathrm{NO}_{2}{ }^{-}$and $\mathrm{H}_{4} \mathrm{SiO}_{4}$ determination; 1 aliquot was filtered and transferred into glass vials for phosphate determination and 1 aliquot was filtered, transferred into glass vials and acidified with $50 \mu \mathrm{l}$ of concentrated $\mathrm{HNO}_{3}{ }^{-}$for dissolved $\mathrm{Mn}$ and $\mathrm{Fe}$ analyses. $\mathrm{O}_{2}$ concentrations before and after the incubation were measured directly in the tanks and in each core using a polarized pre-calibrated microelectrode (OX-500, Unisense). Samples for nutrients were frozen at $-80^{\circ} \mathrm{C}$ and analyzed within $2 \mathrm{wk}$. 
Net fluxes ( $\mu \mathrm{mol} \mathrm{m} \mathrm{m}^{-2} \mathrm{~h}^{-1}$ ) of all measured solutes across the sediment-water interface were calculated according to the following equation:

$$
\text { flux }=\frac{\left(C_{\mathrm{f}}-C_{\mathrm{i}}\right) \times V}{t \times A}
$$

where $C_{\mathrm{f}}$ and $C_{\mathrm{i}}$ are the final and initial concentrations of the target solute $(\mu \mathrm{M}), V$ is the volume of the water phase in the core (1), $t$ is the incubation time (h) and $A$ is the surface of the core $\left(\mathrm{m}^{2}\right)$.

After the incubation for solute flux measurement, a second incubation was conducted to determine $\mathrm{N}_{2}$ production via denitrification, and rates of anaerobic ammonium oxidation (anammox) and dissimilatory nitrate reduction to ammonium (DNRA). In order to simultaneously detect and quantify these 3 processes, ${ }^{15} \mathrm{~N}$-labeling experiments following the revised isotope pairing technique were carried out (Risgaard-Petersen et al. 2003). The 36 sediment cores were left submerged and uncapped, and preincubated again for $6 \mathrm{~h}$ following the procedure described above. After this period, each core was amended with labeled sodium nitrate $\left(\mathrm{Na}^{15} \mathrm{NO}_{3}, 99\right.$ atomic\%) to final concentrations of 5, 10, 25 and $50 \mu \mathrm{M}^{15} \mathrm{NO}_{3}$ (3 replicates for each concentration). The sediment cores were then sealed again with rubber stoppers and incubated in the dark for $8 \mathrm{~h}$ with the stirring system on. At the end of the incubation all the cores were gently mixed to slurry. Subsamples of the slurries were collected with plastic syringes protected with a plastic net and Viton tubing to avoid collection of Marenzelleria individuals, and transferred into $7.7 \mathrm{ml}$ Exetainers to which $100 \mu \mathrm{l} \mathrm{M} \mathrm{ZnCl}_{2}$ was added to stop bacterial activity. An additional $30 \mathrm{ml}$ of each slurry was transferred into each $50 \mathrm{ml}$ centrifuge tube from the cores incubated with 25 and $50 \mu \mathrm{M}{ }^{15} \mathrm{NO}_{3}^{-}$concentrations ( $\mathrm{n}=6$ for each treatment), and immediately frozen at $-80^{\circ} \mathrm{C}$ for later determination of the ${ }^{15} \mathrm{NH}_{4}{ }^{+}$fraction in the ammonium pool. All the remaining slurries from NOB cores were finally sieved through a $500 \mu \mathrm{m}$ mesh net to recover all polychaetes and determine their density and biomass. Wet weight (WW) and dry weights (DW) were measured using a laboratory balance (MS105, Mettler Toledo).

\section{Oxygen consumption by Marenzelleria}

A variable number (1 to 3) of Marenzelleria spp. individuals, together with water filtered through GF/F glass-fiber filters, were collected from NOB mesocosms and placed in $7.7 \mathrm{ml}$ Exetainers $(\mathrm{n}=10)$, taking care to avoid the inclusion of air bubbles. A Clark-type oxygen microelectrode was used for measuring $\mathrm{O}_{2}$ concentrations every $2 \mathrm{~h}$ for an incubation period of $10 \mathrm{~h}$, during which the vials were maintained at the temperature of the sediment incubation. Oxygen concentrations measured after $4 \mathrm{~h}$ of incubation were discarded as they decreased by $>20 \%$ of the initial values. A micrometer manipulator was used to introduce the electrode in the vials in order to avoid that the sample would warm up during the measurement. At the end of the incubation, polychaetes from each Exetainer were recovered, and dried at $60^{\circ} \mathrm{C}$ to constant weight. Oxygen consumption was then calculated as a function of DW $(\mathrm{g})$.

\section{Oxygen, sulfide and pH microelectrode profiles}

For each treatment (HY, NO and NOB), 3 to 6 microprofiles of dissolved oxygen, $\mathrm{H}_{2} \mathrm{~S}$ and $\mathrm{pH}$ were measured in order to determine the depth distribution of dissolved oxygen, total dissolved sulfide and $\mathrm{pH}$. Profiles were determined simultaneously directly inside the mesocosms, using a manual micromanipulator (Unisense) and microsensors with a tip diameter of $50 \mu \mathrm{m}$ (OX-50, $\mathrm{H}_{2} \mathrm{~S}-50, \mathrm{pH}-50$; Unisense). $\mathrm{O}_{2}$ microelectrodes were calibrated each day at $\mathrm{O}_{2}$ saturation and under anoxic conditions using 2-point calibrations according to the manufacturer's recommendation. $\mathrm{H}_{2} \mathrm{~S}$ microelectrodes were calibrated daily in fresh $\mathrm{Na}_{2} \mathrm{~S}$ solutions that were prepared every day with washed and cleaned $\mathrm{Na}_{2} \mathrm{~S}$ crystals in anoxic water and calibrated using the methylene blue method of Cline (1969). pH microelectrodes were calibrated with $\mathrm{pH}$ standards of 4 and 7. Total dissolved sulfide was calculated from the measurement pairs of $\mathrm{H}_{2} \mathrm{~S}$ and $\mathrm{pH}$ for each depth using the first and second dissociation constants of $\mathrm{H}_{2} \mathrm{~S} / \mathrm{HS}^{-}$ and $\mathrm{HS}^{-} / \mathrm{S}^{2-}$.

\section{Laboratory analyses and rate calculations}

Inorganic nutrients $\left(\mathrm{NH}_{4}{ }^{+}, \mathrm{NO}_{3}{ }^{-}, \mathrm{NO}_{2}{ }^{-}\right.$, total dissolved inorganic $\mathrm{PO}_{4}{ }^{3-}$ and $\mathrm{H}_{4} \mathrm{SiO}_{4}$ ) were determined spectrophotometrically on a segmented flow nutrient analyzer system (ALPKEM, Flow Solution IV). Precision was $\pm 0.036 \mu \mathrm{M}$ for $\mathrm{NH}_{4}{ }^{+}, \pm 0.021 \mu \mathrm{M}$ for $\mathrm{NO}_{3}{ }^{-}$, $\pm 0.014 \mu \mathrm{M}$ for $\mathrm{NO}_{2}{ }^{-}, \pm 0.016$ for $\mathrm{PO}_{4}{ }^{3-}$ and \pm 0.036 for $\mathrm{H}_{4} \mathrm{SiO}_{4} \cdot \mathrm{Fe}^{2+}$ and $\mathrm{Mn}^{2+}$ concentrations were determined using a Varian AA240FS fast sequential atomic absorption spectrometer. The precision of the metal analysis was $\pm 0.3 \mu \mathrm{M}$. $\mathrm{CH}_{4}$ was determined by 
headspace analysis with a Fisons 9000 gas chromatograph equipped with a flame ionization detector (precision was $\pm 1 \mathrm{ppb}$ ).

In order to calculate DNRA rates, the total ammonium pool in the slurries was extracted with $2 \mathrm{M} \mathrm{KCl}$. An aliquot of the extract was analyzed spectrophotometrically, while another aliquot was treated with a hypobromite-iodine solution to oxidize ammonium to $\mathrm{N}_{2}$ (Risgaard-Petersen et al. 1995). The abundance of ${ }^{29} \mathrm{~N}_{2}$ and ${ }^{30} \mathrm{~N}_{2}$ of the $\mathrm{N}_{2}$ obtained from the oxidation of $\mathrm{NH}_{4}{ }^{+}$with hypobromite-iodine and of the $\mathrm{N}_{2}$ pool produced by denitrification were determined on an isotope ratio mass spectrometer (Delta V Advantage, Thermo Scientific) coupled via an open-split interface (Conflo IV, Thermo Scientific) to a separation inlet system equipped with a freeze trap, a reduction oven and a packed gas chromatography column (Holtappels et al. 2011).

Co-occurrence of denitrification and anammox was evaluated by plotting the calculated ${ }^{28} \mathrm{~N}_{2}$ production as a function of the added ${ }^{15} \mathrm{~N}$-nitrate. The calculation of in situ denitrification rates, nitrification coupled denitrification $\left(D_{\mathrm{n}}\right)$ and water column nitratedriven denitrification $\left(D_{\mathrm{w}}\right)$ followed the rationale and the equations reported in Nielsen (1992). Rates of DNRA were calculated following Risgaard-Petersen \& Rysgaard (1995), and in situ rates distinguished between DNRA based on nitrate diffusion from the water column $\left(\mathrm{DNRA}_{\mathrm{W}}\right)$ and DNRA coupled to sediment nitrification $\left(\mathrm{DNRA}_{n}\right)$.

\section{Statistical analyses}

Differences between net solute fluxes calculated for each treatment (HY, NO and NOB) were tested using 1-way analysis of variance (ANOVA). Most measured rates were not normally distributed, even after data transformation, and the non-parametric Kruskal-Wallis test was used. The parametric test was used only for $D_{\mathrm{w}}$ rates and $\mathrm{PO}_{4}{ }^{3-}$ fluxes that fulfilled the ANOVA assumptions. Pairwise post hoc comparisons between the 3 treatments (HY, NO and NOB) were done with the Tukey test. The slopes of the regression between $p^{29} \mathrm{~N}_{2}$ and $p^{30} \mathrm{~N}_{2}$ and the amount of added ${ }^{15} \mathrm{NO}_{3}{ }^{-}$in the 3 treatments were compared by means of the analysis of covariance (ANCOVA). Correlations between macrofaunal biomass and solute fluxes were tested using Pearson's correlation coefficient (r), with significant differences set at $\mathrm{p}<0.05$. Statistical analyses were performed with R statistical package. Mean values are reported with associated standard errors.

\section{RESULTS}

\section{Respiration-related fluxes, denitrification and DNRA rates}

The main physicochemical parameters measured in the mesocosms before the incubation began and full statistical results are reported in Appendix 1 (Tables A1 to A4). Solute fluxes measured in the HY and NO treatments had a similar variability (mean coefficients of variation [CV] for all calculated fluxes of 0.71 and 0.70 ). Fluxes in NOB sediments were more variable (mean CV $=1.52$ ), which can be attributed to the variable number of polychaetes in each core. Marenzelleria individuals in the cores varied between 0 and 7 , with an average density of $2041 \pm$ 545 ind. $\mathrm{m}^{-2}$, corresponding to an average dry weight (DW) of $7.67 \pm 2.50 \mathrm{~g} \mathrm{DW} \mathrm{m}^{-2}$.

In the $\mathrm{HY}$ treatments dissolved $\mathrm{O}_{2}$ penetrated to $\sim 0.45 \mathrm{~mm}$, while in the $\mathrm{NO}$ and NOB treatments $\mathrm{O}_{2}$ penetration was $\sim 2$ and $2.5 \mathrm{~mm}$, respectively (Fig. 2). Total sediment oxygen uptake was lower in the HY $\left(-61 \pm 11 \mu \mathrm{mol} \mathrm{m} \mathrm{m}^{-2} \mathrm{~h}^{-1}\right)$ than in the NO treatment $\left(-209 \pm 17 \mu \mathrm{mol} \mathrm{O} \mathrm{m}^{-2} \mathrm{~h}^{-1}\right.$ ) (Fig. 3). Bioirrigation by Marenzelleria significantly increased benthic respiration $\left(-441 \pm 64 \mu \mathrm{mol} \mathrm{O} \mathrm{m}^{-2} \mathrm{~h}^{-1}\right.$ ) (Kruskal-Wallis ANOVA, $H_{2,33}=29.13, \mathrm{p}<0.001$ ) (Fig. 3). In the NOB treatment there was a highly significant and positive linear correlation between sediment oxygen demand and the dry weight of Marenzelleria $(y=-22.21 x-$ $271.02, r=0.86, p<0.001)$. The respiration of the polychaetes alone, calculated from the incubation of Marenzelleria individuals in filtered water, was $20.7 \mu \mathrm{mol}$ $\mathrm{O}_{2} \mathrm{~g}^{-1} \mathrm{DW} \mathrm{h}^{-1}$. Multiplication by the average biomass of Marenzelleria in NOB cores yielded a corresponding rate of $158.7 \pm 51.8 \mu \mathrm{mol} \mathrm{m} \mathrm{m}^{-2} \mathrm{~h}^{-1}$, a contribution of about $36 \%$ to total sediment respiration. Surface sediment contribution to total respiration (47\%) was considered equivalent to that measured in NO cores. The contribution of burrow structures (17\%) was calculated by subtraction of Marenzelleria respiration and NO core respiration from total benthic respiration measured in NOB cores.

Dissolved sulfide was detectable at 0.5, 2.8 and 2.0 $\mathrm{mm}$ depth in the HY, NO and NOB treatments, respectively (Fig. 2). The depth of sulfide appearance overlapped with the presence of Marenzelleria, indicating their sulfide tolerance (Schneider 1996). From visual inspections it was evident that the polychaetes burrowed down to $7-8 \mathrm{~cm}$ in the sediment. Net fluxes of dissolved iron and methane were low and insignificantly different in the 3 treatments (Kruskal-Wallis ANOVA, $H_{2,33}=5.30$ and 2.02, respectively, $\mathrm{p}>0.05$ ) 

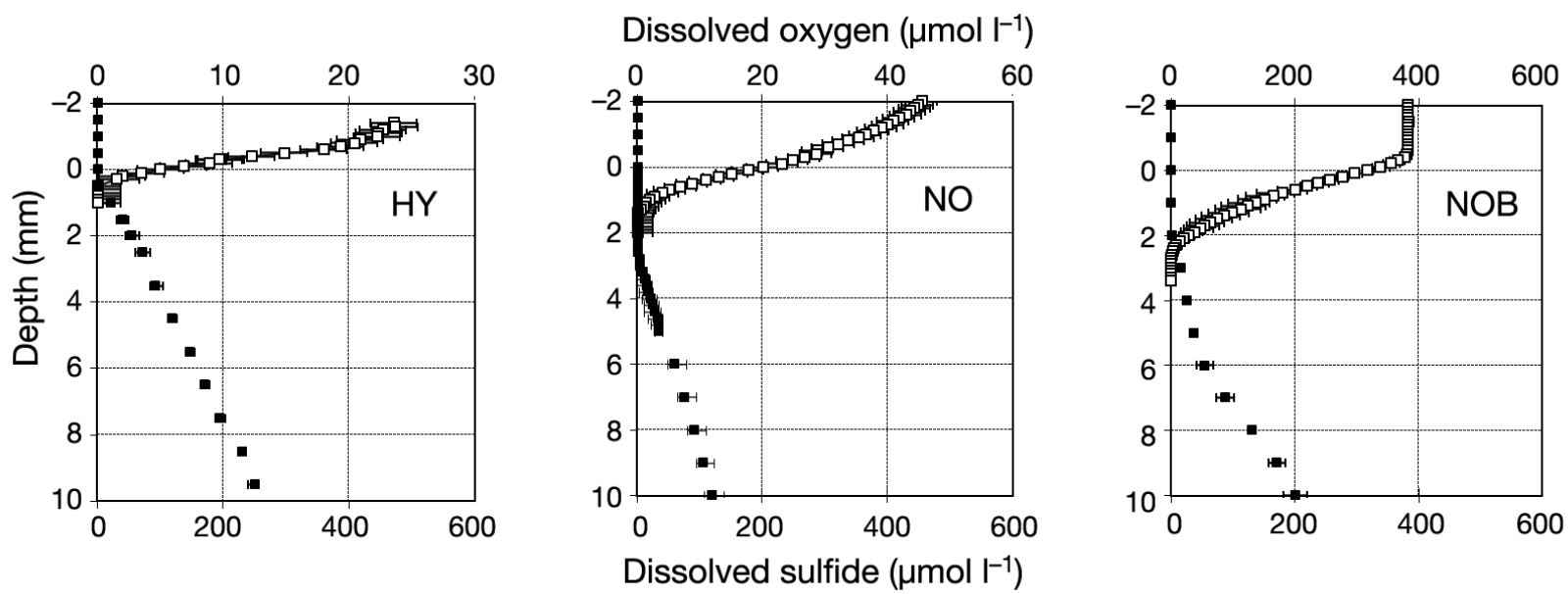

Fig. 2. Microelectrode profiles of dissolved oxygen $(\square)$ and total dissolved sulfide $(\boldsymbol{\square})$ for the hypoxic (HY), normoxic (NO) and normoxic-bioturbated (NOB) treatments. Means $\pm \mathrm{SD}, \mathrm{n}=6$

(Fig. 3). There were positive correlations between these fluxes and the biomass of Marenzelleria $(y=$ $0.50 x-5.8, \mathrm{r}=0.92, \mathrm{p}<0.001$ and $y=0.04 x-0.01, \mathrm{r}=$ $0.68, \mathrm{p}<0.05) . \mathrm{Mn}^{2+}$ was always released to the water
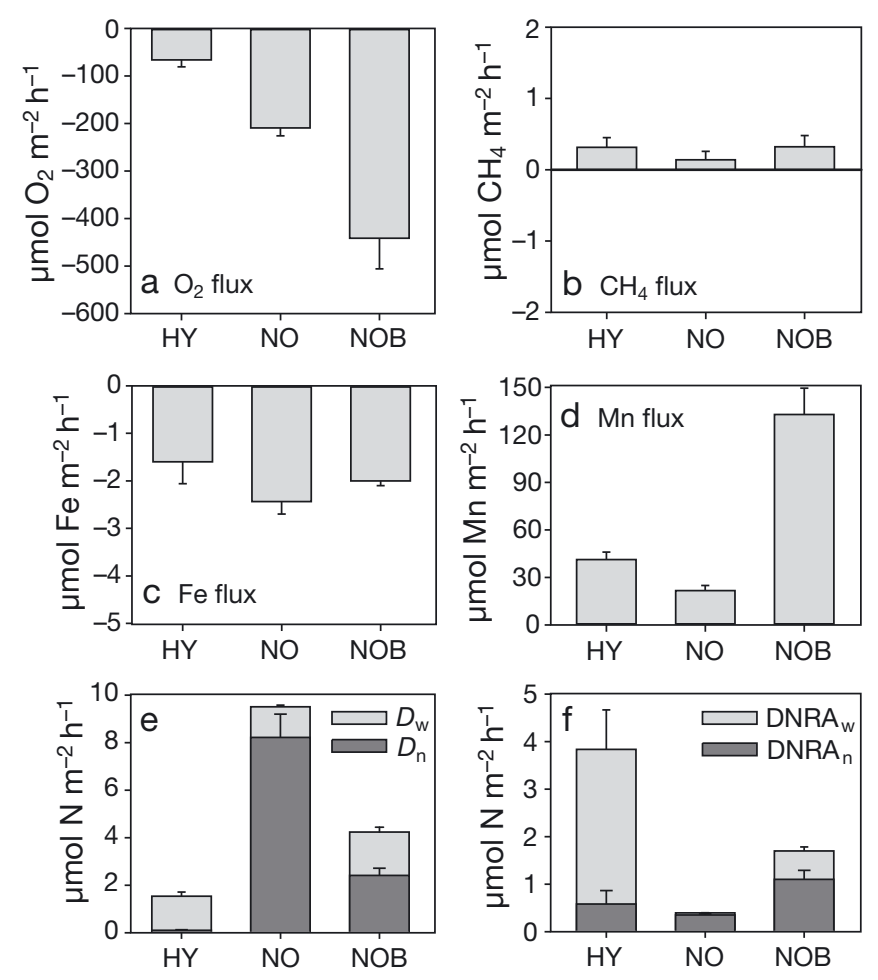

Fig. 3. Net fluxes of (a) oxygen, (b) methane, and dissolved (c) iron and (d) manganese at the sediment-water interface; (e) rates of nitrification-coupled $\left(D_{\mathrm{n}}\right)$ and of water column nitrate denitrification $\left(D_{\mathrm{w}}\right)$; (f) rates of dissimilatory nitrate reduction to ammonium coupled to nitrification (DNRA $A_{n}$ ) and fueled by water column nitrate $\left(\mathrm{DNRA}_{\mathrm{w}}\right)$ measured in intact sediment cores. Mean $\pm \mathrm{SE}, \mathrm{n}=12$; positive fluxes are from the sediment to the water column column. The highest flux was measured in the NOB treatment $\left(133 \pm 17 \mu \mathrm{mol} \mathrm{m} \mathrm{m}^{-2} \mathrm{~h}^{-1}\right)$ followed by the hypoxic $\left(41 \pm 5 \mu \mathrm{mol} \mathrm{m} \mathrm{m}^{-2} \mathrm{~h}^{-1}\right)$ and normoxic treatments $\left(22 \pm 3 \mu \mathrm{mol} \mathrm{m}{ }^{-2} \mathrm{~h}^{-1}\right)$ (Kruskal-Wallis ANOVA, $H_{2,33}=26.02, \mathrm{p}<0.001$, Tukey, $\mathrm{p}<0.05$ ) (Fig. 3). Evidently, bioturbation by the polychaete stimulated the release of $\mathrm{Mn}^{2+}$, as suggested by the significant positive correlation between $\mathrm{Mn}^{2+}$ efflux and Marenzelleria biomass $(y=5.96 x+87.18, r=0.90, p<0.001)$.

There was no relationship between genuine $\mathrm{N}_{2}$ production and the amount of added ${ }^{15} \mathrm{~N}$-nitrate, suggesting that anammox activity was insignificant (Risgaard-Petersen et al. 2003). Rates of denitrification were low in all treatments $\left(<10 \mu \mathrm{mol} \mathrm{N} \mathrm{m} \mathrm{N}^{-2} \mathrm{~h}^{-1}\right)$ compared to sediment oxygen uptake and net $\mathrm{Mn}^{2+}$ release (Fig. 3). Differences between the treatments were largely due to variations in the amount of $D_{n}$. The contribution of $D_{\mathrm{n}}$ to total denitrification was highest in NO (87\%), intermediate in NOB (57\%) and lowest in HY $(7 \%)(8.2 \pm 1.0,2.4 \pm 0.3,0.1 \pm 0.0 \mu \mathrm{mol}$ $\mathrm{m}^{-2} \mathrm{~h}^{-1}$, respectively) (Fig. 3). Marenzelleria biomass and $D_{\mathrm{n}}$ were not correlated $(\mathrm{r}=0.09, \mathrm{p}=0.78) . D_{\mathrm{w}}$ was comparable in the $\mathrm{HY}, \mathrm{NO}$ and NOB treatments (1-way ANOVA, $F_{2,33}=2.84, \mathrm{p}=0.07$ ). There was a positive correlation between the polychaete biomass and $D_{\mathrm{w}}$, but the overall effect was quantitatively small $(y=0.07 x+1.32, r=0.80, p<0.01)$.

The combined analysis of ${ }^{29} \mathrm{~N}_{2}$ and ${ }^{30} \mathrm{~N}_{2}$ production relative to added ${ }^{15} \mathrm{NO}_{3}{ }^{-}$highlights some differences concerning nitrification and denitrification activity in the 3 experimental conditions (Fig. 4). Overall, there was a positive and significant correlation between the production $(p)$ of ${ }^{29} \mathrm{~N}_{2}$ and ${ }^{30} \mathrm{~N}_{2}$ and the concentration of added ${ }^{15} \mathrm{NO}_{3}{ }^{-}$in all treatments, with $\mathrm{HY}$ as the only exception ( $t$-test, $\mathrm{p}>0.05)$. In NO, the slopes of the linear regression between $p^{29} \mathrm{~N}_{2}$ and $p^{30} \mathrm{~N}_{2}$ and the 
${ }^{15} \mathrm{NO}_{3}{ }^{-}$concentration were not statistically different (ANCOVA, $p=0.735$ ). In NOB, the production of ${ }^{30} \mathrm{~N}_{2}$ was more stimulated than the production of ${ }^{29} \mathrm{~N}_{2}$ at increasing ${ }^{15} \mathrm{NO}_{3}{ }^{-}$concentrations (ANCOVA, $\mathrm{p}<0.001$ )

DNRA was detected in all treatments, but rates were generally $<4 \mu \mathrm{mol} \mathrm{N} \mathrm{m}{ }^{-2} \mathrm{~h}^{-1}$ (Fig. 3). Differences between the 3 treatments were significant and inversely proportional to denitrification rates: highest rates were found in the HY treatment, while lowest rates were measured in the NO treatment (KruskalWallis ANOVA, $H_{2,15}=10.25, \mathrm{p}<0.01$, Tukey, $\mathrm{p}<$ 0.05 ) (Fig. 3). There was no significant correlation between animal biomass and DNRA $(r=0.42, p=0.41)$.

\section{Nutrient fluxes}

Soluble reactive phosphorus (SRP) fluxes were low

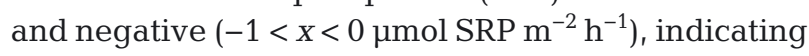
uptake of phosphorus by the sediment (Fig. 5). The uptake was stronger in the NOB treatment (1-way ANOVA, $F_{2,33}=3.70, \mathrm{p}<0.05$, Tukey, $\left.\mathrm{p}<0.05\right)$. NOB treatment showed the highest dissolved silica fluxes (60.3 $\pm 5.4 \mu \mathrm{mol} \mathrm{H}_{4} \mathrm{SiO}_{4} \mathrm{~m}^{-2} \mathrm{~h}^{-1}$ ), followed by the $\mathrm{HY}$ treatment $\left(49.6 \pm 2.6 \mu \mathrm{mol} \mathrm{H}_{4} \mathrm{SiO}_{4} \mathrm{~m}^{-2} \mathrm{~h}^{-1}\right)$ and the NO treatment $\left(40.0 \pm 1.3 \mu \mathrm{mol} \mathrm{H}_{4} \mathrm{SiO}_{4} \mathrm{~m}^{-2} \mathrm{~h}^{-1}\right)$ (Kruskal-Wallis ANOVA, $H_{2,33}=13.92, \mathrm{p}<0.001$, Tukey, $\mathrm{p}<0.05$ ). There was also a positive correlation between the biomass of Marenzelleria and the flux of dissolved silica $(y=1.62 x+47.89, r=0.75, p<0.01)$.

Sediments from all treatments were net sources of dissolved inorganic nitrogen (DIN). Measured fluxes for the NO, NOB and HY treatments were $9.4 \pm 1.1$, $31.7 \pm 5.4$ and $40.6 \pm 2.6 \mu \mathrm{mol} \mathrm{DIN} \mathrm{m}^{-2} \mathrm{~h}^{-1}$, respectively (Fig. 5). In the HY treatment, DIN fluxes were almost entirely comprised of ammonium release $(39 \pm$ $2.0 \mu \mathrm{mol} \mathrm{NH}_{4}^{+} \mathrm{m}^{-2} \mathrm{~h}^{-1}$ ), whereas the nitrite and nitrate fluxes were negligible. In the NOB treatment, the ammonium flux was only $\sim 30 \%$ of the DIN flux $\left(11.7 \pm 3.9 \mu \mathrm{mol} \mathrm{NH}{ }_{4}{ }^{+} \mathrm{m}^{-2} \mathrm{~h}^{-1}\right)$. In the NO treatment, the DIN flux was entirely represented by nitrate efflux, while the ammonium flux was slightly nega-

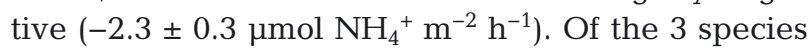
comprising DIN, only the ammonium flux was positively correlated with Marenzelleria biomass ( $y=$ $1.32 x+1.54, \mathrm{r}=0.85, \mathrm{p}<0.001)$.

The denitrification efficiency (DE) was calculated from the ratio of the inorganic nitrogen fluxes and the $\mathrm{N}_{2}$ production via denitrification. This is the amount of mineralized nitrogen that is permanently removed from the sediment as $\mathrm{N}_{2}$. DE was highest in the NO treatment $(50 \%)$ and decreased significantly in NOB $(16 \%)$ and HY $(4 \%)$ treatments.
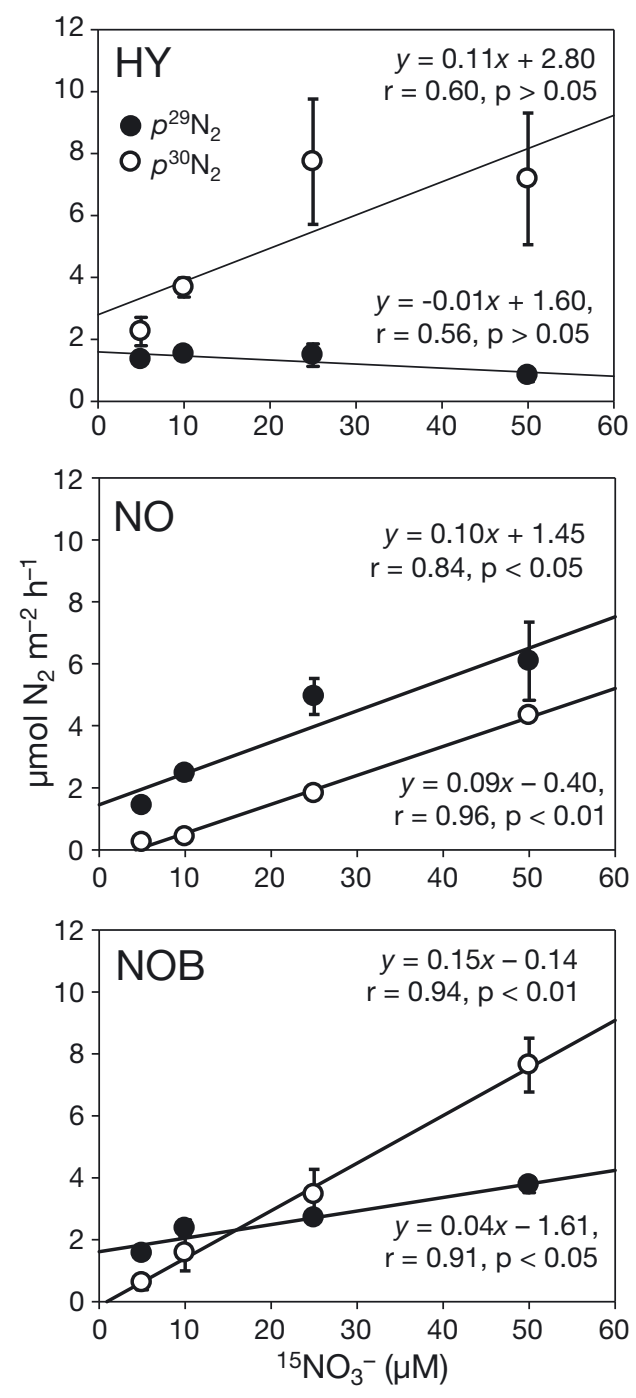

Fig. 4. Production $(p)$ of ${ }^{29} \mathrm{~N}_{2}$ and ${ }^{30} \mathrm{~N}_{2}$ as a function of the concentration of ${ }^{15} \mathrm{NO}_{3}{ }^{-}$in the core water phase. In the hypoxic treatment $(\mathrm{HY})$, the slopes of the linear regressions between $p^{29} \mathrm{~N}_{2}$ and $p^{30} \mathrm{~N}_{2}$ and $\left[{ }^{15} \mathrm{NO}_{3}{ }^{-}\right]$were not significantly different from zero; in the normoxic treatment (NO), they were $>0$ and parallel, while in the normoxic-bioturbate treatment (NOB), $p^{30} \mathrm{~N}_{2}$ was more stimulated than $p^{29} \mathrm{~N}_{2}$ by increasing ${ }^{15} \mathrm{NO}_{3}{ }^{-}$concentrations

\section{DISCUSSION}

\section{Experimental design}

Previous experiments of the effects of bioturbation and bioirrigation have been conducted using sieved fauna-free sediments with short conditioning periods (Bartoli et al. 2000, 2009, Hietanen et al. 2007) with the main purpose of reducing background variability. The disadvantage of this approach is that sediment-sieving changes the grain size distribution, 

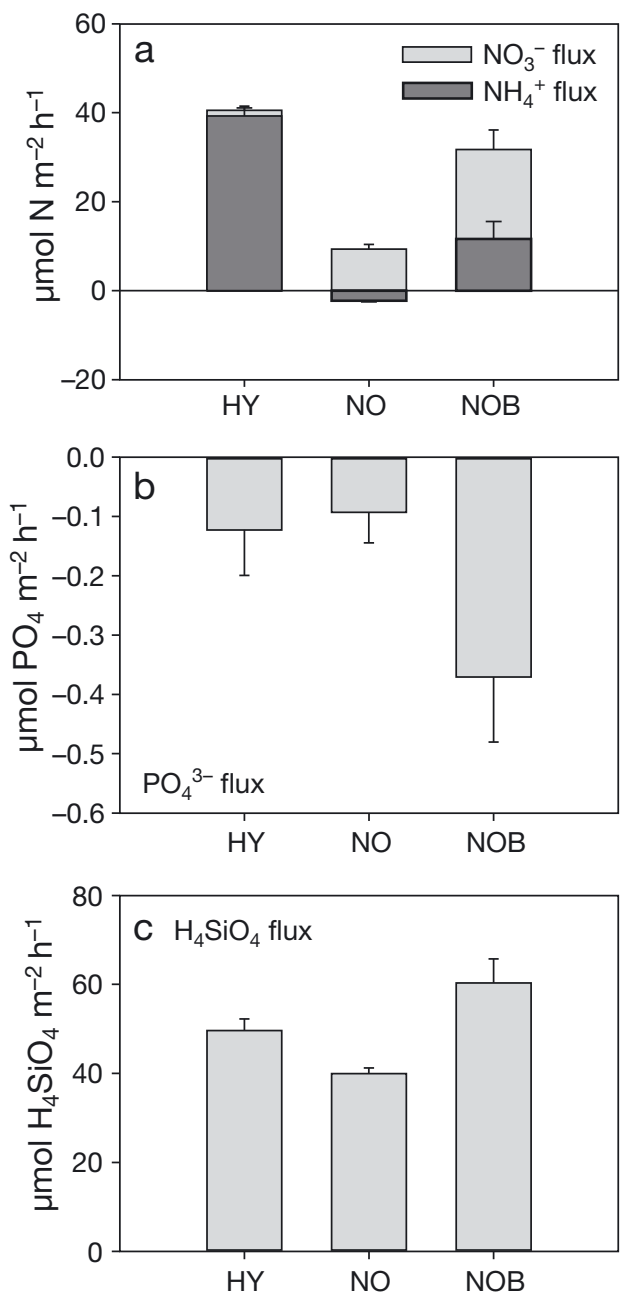

Fig. 5. Net fluxes of (a) ammonium and nitrate, (b) reactive phosphorus and (c) silica measured in intact sediment cores. Means $\pm \mathrm{SD}, \mathrm{n}=12$; positive fluxes are from the sediment to the water column

reduces bacterial biomass and changes the microbial community composition by favoring fast-growing bacteria (Langezaal et al. 2003, Stocum \& Plante 2006). Furthermore, in the case of muddy sediment, animal burrows are poorly consolidated (Karlson et al. 2005).

In the present experiment, sediments that were free of macrofauna were collected from a deep anoxic site and transferred into mesocosms with minimal disturbance, except for replacement of overlying anoxic with normoxic bottom water (NO) and the addition of macrofauna (NOB). The NOB treatment underwent a relatively long conditioning period after addition of macrofauna (48 d), allowing the consolidation of new burrow structures, their colonization by microbial communities and the establishment of steep gradients that characterize bioturbated sedi- ments. Since the conditioning time was long, it is likely that Marenzelleria individuals were not actively burrowing during our sampling and incubation procedures, and the number of individuals recovered in the cores at the end of incubations reflected the patchy distribution of Marenzelleria spp. We thus believe that the rates we report are not affected by density-dependent features or by edge-effects associated with elevated numbers of burrowing organisms on a limited sediment volume. In this respect, indirect evidence is provided by the linearity of most measured process rates at different animal densities.

\section{Contrasting respiration and nutrient fluxes in the HY, NO and NOB treatments}

The most conspicuous characteristic of our experiments was that the change from hypoxic to normoxic conditions stimulated sediment oxygen consumption rates by a factor of 3.4 and nitrification-coupled denitrification by a factor of $>6$, while the $\mathrm{Mn}^{2+}$ efflux decreased by $50 \%$ and the efflux of ammonium was stopped. Normoxia apparently enhanced aerobic respiration rates and $\mathrm{O}_{2}$-consuming chemoautotrophic processes, such as nitrification, and the oxidation of reduced compounds, such as $\mathrm{NH}_{4}{ }^{+}, \mathrm{Mn}^{2+}$, $\mathrm{Fe}^{2+}$ and dissolved sulfide. The decrease in the $\mathrm{Mn}^{2+}$ efflux from the HY to the NO treatment was stoichiometrically equivalent to consumption of $20 \mu \mathrm{mol} \mathrm{O}_{2}$ $\mathrm{m}^{-2} \mathrm{~h}^{-1}$. This amount corresponds to $14 \%$ of the increase in total oxygen uptake (TOU) from the HY to the NO treatment. The oxygen consumption due to nitrification was $36 \mu \mathrm{mol} \mathrm{O} \mathrm{O}^{-2} \mathrm{~h}^{-1}$, and represented an additional $26 \%$ of the increase in TOU from the HY to the NO treatment. Overall, at least $40 \%$ of the increased oxygen uptake was not used for aerobic respiration, but in bacterial and chemical inorganic oxidation processes.

The additional doubling in the total oxygen uptake rates in the NOB treatment compared to the NO treatment was mostly due to respiration by the polychaetes $(67 \%)$ and to additional oxidation in the burrow walls. We estimated the oxygen consumption in the Marenzelleria burrow walls by subtracting the oxygen consumption in the NO treatment and the Marenzelleria respiration in the Exetainers from the total oxygen consumption measured in the NOB treatment. The calculated respiration within the burrow walls was $73.3 \pm 22.9 \mu \mathrm{mol} \mathrm{m} \mathrm{m}^{-2} \mathrm{~h}^{-1}$, corresponding to $17 \%$ of total respiration. The measured oxygen consumption rate by Marenzelleria (20.7 $\mu_{\mathrm{mol} \mathrm{O}} \mathrm{g}^{-1}$ $\mathrm{DW} \mathrm{h}^{-1}$ ) is considered a maximum respiration rate, 
because $\mathrm{O}_{2}$-saturated water was used in the incubations, which is not likely the case within the burrows where oxygen concentrations were expected to be substantially lower. Since chemoautotrophic and chemical oxidation processes such nitrification and manganese, iron and sulfide oxidation were probably also stimulated by the greater exposure of sediment surface in the burrow walls, our estimate of the oxygen consumption rates in the burrow walls is likely underestimated.

Overall, however, the increased oxygen uptake measured in the sediments with Marenzelleria was insufficient to oxidize all reduced compounds, which were produced during anaerobic respiration deeper in the sediment. This is clearly seen by the increased efflux of $\mathrm{Mn}^{2+}$ and $\mathrm{NH}_{4}{ }^{+}$in the NOB treatment compared to the NO treatment. The increase in the flux of $\mathrm{Mn}^{2+}$ and $\mathrm{NH}_{4}^{+}$was higher than that expected from the increase in surface area for solute exchange with the water column by the Marenzelleria burrows and suggests that Marenzelleria stimulated anaerobic bacterial processes. This is in agreement with the reported stimulation of bacterial sulfate reduction by Marenzelleria (Kristensen et al. 2011). The presence of free sulfide in the Marenzelleria-inhabited zone in our study supports this interpretation. High sulfide concentrations would also inhibit nitrification rates and stimulate DNRA (Burgin \& Hamilton 2007). In addition, increased sulfide production can explain the low fluxes of $\mathrm{Fe}^{2+}$, because $\mathrm{Fe}^{2+}$ production would have been efficiently buffered by the formation of iron sulfides. Stimulation of anaerobic metabolism within the burrow walls could also explain the increased silica flux, because the ingestion of diatoms by Marenzelleria and the irrigation of the burrow walls due to the pumping activity of Marenzelleria (Quintana et al. 2011) would increase the release of dissolved silica to the water.

Our study confirms the scavenging effect of bioturbation on SRP (Rozan et al. 2002, Norkko et al. 2012), but this effect was relatively weak. This can be explained by the fact that the present experiments were carried out with sediments conditioned for $>2$ mo before the beginning of the measuring period. SRP release from the sediment following the establishment of anoxia or hypoxia is generally coupled to the reduction of iron oxyhydroxides and can be intense, but limited in time (Rozan et al. 2002). Once the reactive iron oxyhydroxide pool is consumed sorbed phosphorus is quickly released and the subsequent SRP efflux would only be supported by anaerobic carbon degradation rates and will slow down considerably. This would explain the low fluxes of
SRP in the hypoxic treatment. Under normoxic conditions, SRP release would be reduced or the flux direction would even be reversed as the re-oxidation of reduced metal pools would scavenge SRP from the water phase. This effect may be further enhanced by bioturbation (Rozan et al. 2002). It appears that a significant scavenging capacity in the NO and NOB treatments persisted even after the 2 mo long conditioning period.

\section{Denitrification and DNRA rates under $\mathrm{HY}$, NO and NOB conditions}

The low rates of $D_{\mathrm{w}}$ and $\mathrm{DNRA}_{\mathrm{w}}$ in all treatments were likely due to the low concentrations of $\mathrm{NO}_{3}{ }^{-}$in the overlying water $(2.3$ to $3.8 \mu \mathrm{M})$. This observation is common to many marine environments and many Baltic Sea sediments with low bottom water nitrate concentrations (Deutsch et al. 2010). In such systems, the removal of nitrogen as $\mathrm{N}_{2}$ depends on the benthic oxygen uptake to support $D_{\mathrm{n}}$ (Eyre \& Ferguson 2009). The 6-fold higher denitrification rates (from 1.5 to $9.5 \mu \mathrm{mol} \mathrm{N} \mathrm{m}^{-2} \mathrm{~h}^{-1}$ ) and 10-fold lower rates of DNRA (from 3.8 to $0.4 \mu \mathrm{mol} \mathrm{N} \mathrm{m}{ }^{-2} \mathrm{~h}^{-1}$ ) in the $\mathrm{NO}$ treatment compared to the HY treatment indicate higher nitrogen loss and less efficient recycling of inorganic nitrogen in the NO treatment. Our results suggest that the increase of total denitrification was due to the formation of a thicker oxic surface layer that allowed nitrification to occur, which, in turn, generated nitrate to support the increased denitrification rates. This interpretation is also supported by the deeper oxygen penetration depth measured in the NO and NOB treatments compared to the HY treatment. Normoxic conditions would have resulted in increased $\mathrm{N}_{2}$ loss and provided a negative feedback mechanism for nitrogen regeneration.

In the Baltic, colonization by macrofauna, particularly of the invasive genus Marenzelleria, is expected once normoxia is established (Schiedek 1997, Leppäkoski et al. 2002, Karlson et al. 2011). Our results indicate a $50 \%$ decrease in denitrification and a 3fold increase of DNRA in sediment inhabited by Marenzelleria compared to normoxic non-bioturbated sediments, resulting in a net stimulation effect of denitrification by bottom water oxygenation of only a factor 3 compared to the HY treatment. This stimulation is only due to differences in $D_{\mathrm{n}}$, since the contribution of $D_{\mathrm{w}}$ was not significantly different between the treatments.

This result is unusual, because it is commonly thought that denitrification is stimulated by the pre- 
sence of macrofauna (Svensson 1998, Svensson et al. 2001). For example, Pelegri et al. (1994) measured a 3- and 5-fold increase of $D_{\mathrm{n}}$ and $D_{\mathrm{w}}$, respectively, in the presence of a very large number of the amphipod Corophium volutator (19800 ind. $\mathrm{m}^{-2}$ ). Tuominen et al. (1999) measured a 1.5-fold increase of $D_{\mathrm{n}}$ in sediments with 1500 ind. $\mathrm{m}^{-2}$ of the amphipod Monoporeia affinis, and Nizzoli et al. (2007) measured a 3 fold increase of $D_{\mathrm{w}}$ in estuarine sediments with the polychaete Nereis spp. However, our results are in agreement with other published studies on Marenzelleria, which suggest that this organism does not stimulate denitrification (Karlson et al. 2005, Hietanen et al. 2007, Kristensen et al. 2011). Our findings indicate that Marenzelleria even reduced denitrification rates in comparison with oxidized non-bioirrigated sediment and this may be due to the sulfidic conditions within the burrows (Kristensen et al. 2011).

The concentration series conducted in our ${ }^{15} \mathrm{~N}$ labeling experiments allowed us to assess the simultaneous occurrence of anammox and denitrification as potential $\mathrm{N}_{2}$-producing processes (RisgaardPetersen et al. 2003, Trimmer et al. 2006, Racchetti et al. 2011). Since genuine ${ }^{28} \mathrm{~N}_{2}$ production was constant and independent of the concentrations of added labeled nitrate, anammox did not appear to contribute significantly to $\mathrm{N}_{2}$ production (Trimmer et al. 2006).

Stimulation of ${ }^{30} \mathrm{~N}_{2}$ production in the bioturbated cores compared to normoxic non-bioturbated ones (Fig. 4) was possibly due to active transport of ${ }^{15} \mathrm{NO}_{3}{ }^{-}$ from the water column in Marenzelleria burrows. Burrow walls were likely anoxic and denitrifiers would have primarily reduced ${ }^{15} \mathrm{NO}_{3}{ }^{-}$within burrows. The low ${ }^{29} \mathrm{~N}_{2}$ production rates suggest that nitrification was suppressed. This is because nitrification would have produced new ${ }^{14} \mathrm{NO}_{3}{ }^{-}$from ${ }^{14} \mathrm{NH}_{4}{ }^{+}$. The new ${ }^{14} \mathrm{NO}_{3}{ }^{-}$would have been used together with ${ }^{15} \mathrm{NO}_{3}{ }^{-}$and allowed the production of ${ }^{29} \mathrm{~N}_{2}$. For the same reasons, ${ }^{29} \mathrm{~N}_{2}$ production was insignificant under hypoxic conditions, but, in addition, the production of ${ }^{30} \mathrm{~N}_{2}$ was lower compared to that in bioturbated sediments due to the absence of burrow-associated new sediment surfaces.

The observation that denitrification of water column nitrate was not significantly different in the 3 experimental treatments is somewhat surprising, as hypoxia should have reduced the diffusion length of nitrate to the denitrification zone. In addition, bioturbation by Marenzelleria should have increased the sediment surface area through which nitrate could diffuse and supported higher $D_{\mathrm{w}}$, as suggested for other burrowers (Nizzoli et al. 2007). In our system, however, dissolved sulfide increased close to the sediment-water interface in the hypoxic and bioturbated treatments, and sulfide toxicity to denitrifiers may have compensated the effects of a shorter diffusion distance (Burgin \& Hamilton 2007, Aelion \& Warttinger 2010).

Higher sulfate reduction rates in the presence of Marenzelleria could also explain the higher DNRA rates in the NOB treatment. Both hypoxia and the activity of Marenzelleria have been shown to increase sulfate reduction rates (Kristensen et al. 2011). High DNRA rates were also reported from sulfidic sediments that receive abundant labile organic carbon, e.g. sediment from affected, eutrophic systems and below mussel and fish farms (Brunet \& GarciaGil 1996, Christensen et al. 2000, Nizzoli et al. 2006). Based on indirect evidence, Karlson et al. (2005) even suggested that DNRA was the main pathway of nitrate removal in Baltic Sea sediment. Our results suggest that DNRA only dominates over denitrification under hypoxic conditions and that ammonium regeneration via DNRA only represented a small fraction of the total recycled inorganic nitrogen $(\sim 10 \%)$, due to very low nitrate in the bottom water.

\section{Summary and conclusions}

This experimental study provides direct evidence of the anticipated recovery effects following recolonization of previously anoxic sediments by bioirrigating and bioturbating macrofauna in the Baltic Sea. Data from recent modeling studies emphasize the beneficial aspects of the invasive polychaete Marenzelleria spp. in counteracting eutrophication by increasing phosphorus retention and carbon mineralization (Norkko et al. 2012). The intense bioirrigation activity of this species may alter key sediment features, reduce the pool of labile organic carbon, and enhance phosphorus retention due to co-precipitation with iron oxyhydroxides. Modeling of a $10 \mathrm{yr}$ long data set suggests that the colonization of Baltic Sea sediment by Marenzelleria would improve the quality of the benthic system through enhanced phosphorus retention in Baltic Sea sediment (Norkko et al. 2012). As a consequence, the frequency and risk of water column anoxia may be substantially reduced.

Our study provides data to test the predictions of the Norkko et al. model after the first months and presents new information on the behavior of nitrogen and silica and the associated changes in aerobic and 
anaerobic respiration rates. Our findings suggest that the Marenzelleria-related scavenging effect of reactive phosphorus, while apparent, was weak. The change from hypoxic to normoxic macrofauna-free conditions led to better retention of silica and greater conversion of fixed nitrogen to $\mathrm{N}_{2}$ gas. This would decrease the amount of recycled nutrients that would be available for primary production.

The stimulation of anaerobic metabolism, the enhanced release of total inorganic nitrogen and silica, and the reduced $\mathrm{N}_{2}$ loss rates in the presence of Marenzelleria imply that the bioturbated treatment resulted in relatively higher recycling rates of fixed nitrogen compared to the normoxic treatment without infauna. Overall, these results suggest that, on the time scale of our experimental setup, Marenzelleria counteracted some beneficial effects that arose due to benthic oxygenation. It is apparent that the observed strong contrasts in biogeochemical flux characteristics and microbial rates have large implications for recovering aquatic ecosystems in the Baltic. Nevertheless, although we conducted our study over a substantially longer time period than previous studies, the experiment was still short compared to the long-term recovery expected for natural ecosystems of the Baltic, if effective nutrient-loading reduction measures are implemented (Meier et al. 2011). This emphasizes the need for extending the duration of these mesocosm experiments to substantially longer time periods.

Acknowledgements. We thank the staff of the Askö laboratory for support during sampling and setup of the mesocosm experiments, and Susanne Eriksson (University of Gothenburg) for help with the hypoxia control system. We acknowledge the staff of the chemical laboratory at Department of Systems Ecology (Stockholm University) for nutrient analysis, and Hildred Crill for language advice. S.B. thanks Hannah Marchant (MPI Bremen) and Loreto De Brabandere (University of Southern Denmark) for technical advice and help with $\mathrm{N}$ isotope data interpretation. We also thank 3 anonymous reviewers for their constructive comments. Financial support for this study was provided by the 2 Formas projects 'Managing Baltic Nutrients' and 'BEAM' (V.B.); the BOX project (L.R.); Stockholm University Marine Research Centre (S.B.), and a faculty grant from Stockholm University (J.S.G.).

\section{LITERATURE CITED}

Aelion CM, Warttinger U (2010) Sulfide inhibition of nitrate removal in coastal sediments. Estuaries Coasts 33: 798-803

Aller RC, Aller JY (1998) The effect of biogenic irrigation intensity and solute exchange on diagenetic reaction rates in marine sediments. J Mar Res 56:905-936
Bartoli M, Nizzoli D, Welsh DT, Viaroli P (2000) Short-term influence of recolonisation by the polycheate worm Nereis succinea on oxygen and nitrogen fluxes and denitrification: a microcosm simulation. Hydrobiologia 431: 165-174

Bartoli M, Longhi D, Nizzoli D, Como S, Magni P, Viaroli P (2009) Short term effects of hypoxia and bioturbation on solute fluxes, denitrification and buffering capacity in a shallow dystrophic pond. J Exp Mar Biol Ecol 381: 105-113

Blank M, Laine AO, Juerss K, Bastrop R (2008) Molecular identification key based on PCR/RFLP for three polychaete sibling species of the genus Marenzelleria, and the species' current distribution in the Baltic Sea. Helgol Mar Res 62:129-141

Brunet RC, Garcia-Gil LJ (1996) Sulfide-induced dissimilatory nitrate reduction to ammonia in anaerobic freshwater sediments. FEMS Microbiol Ecol 21:131-138

Burgin AJ, Hamilton SK (2007) Have we overemphasized the role of denitrification in aquatic ecosystems? A review of nitrate removal pathways. Front Ecol Environ 5:89-96

Christensen PB, Rysgaard S, Sloth NP, Dalsgaard T, Schwærter S (2000) Sediment mineralization, nutrient fluxes, denitrification and dissimilatory nitrate reduction to ammonium in an estuarine fjord with sea cage trout farms. Aquat Microb Ecol 21:73-84

Cline JD (1969) Spectrophotometric determination of hydrogen sulfide in natural waters. Limnol Oceanogr 14: 454-458

Conley DJ, Bjorck S, Bonsdorff E, Carstensen J and others (2009) Hypoxia-related processes in the Baltic Sea. Environ Sci Technol 43:3412-3420

Deutsch B, Forster S, Wilhelm M, Dippner JW, Voss M (2010) Denitrification in sediments as a major nitrogen sink in the Baltic Sea: an extrapolation using sediment characteristics. Biogeosciences 7:3259-3271

Diaz RJ, Rosenberg R (2008) Spreading dead zones and consequences for marine ecosystems. Science 321:926-929

Elmgren R (2001) Understanding human impact on the Baltic ecosystem: changing views in recent decades. Ambio 30:222-231

Eyre BD, Ferguson AJP (2009) Denitrification efficiency for defining critical loads of carbon in shallow coastal ecosystems. Hydrobiologia 629:137-146

Gambi C, Bianchelli S, Perez M, Invers O, Ruiz JM, Danovaro R (2009) Biodiversity response to experimental induced hypoxic-anoxic conditions in seagrass sediments. Biodivers Conserv 18:33-54

> Glud RN (2008) Oxygen dynamics of marine sediments. Mar Biol Res 4:243-289

Gray JS, Wu RSS, Or YY (2002) Effects of hypoxia and organic enrichment on the coastal marine environment. Mar Ecol Prog Ser 238:249-279

Hedman JE, Gunnarsson JS, Samuelsson G, Gilbert F (2011) Particle reworking and solute transport by the sedimentliving polychaetes Marenzelleria neglecta and Hediste diversicolor. J Exp Mar Biol Ecol 407:294-301

Hietanen S, Laine AO, Lukkari K (2007) The complex effects of the invasive polychaetes Marenzelleria spp. on benthic nutrient dynamics. J Exp Mar Biol Ecol 352:89-102

Holtappels M, Lavik G, Jensen MM, Kuypers MMM (2011) ${ }^{15} \mathrm{~N}$-labeling experiments to dissect the contributions of heterotrophic denitrification and anammox to nitrogen removal in the OMZ waters of the ocean. In: Martin GK 
(ed) Methods in enzymology, Book 486. Academic Press, New York, NY, p 223-251

Karlson K, Rosenberg R, Bonsdorff E (2002) Temporal and spatial large-scale effects of eutrophication and oxygen deficiency on benthic fauna in Scandinavian and Baltic waters - a review. Oceanogr Mar Biol Annu Rev 40: $427-489$

Karlson K, Hulth S, Ringdahl K, Rosenberg R (2005) Experimental recolonisation of Baltic Sea reduced sediments: survival of benthic macrofauna and effects on nutrient cycling. Mar Ecol Prog Ser 294:35-49

Karlson AML, Naslund J, Ryden SB, Elmgren R (2011) Polychaete invader enhances resource utilization in a species-poor system. Oecologia 166:1055-1065

Kristensen E, Kostka JE (2005) Macrofaunal burrows and irrigation in marine sediment: microbiological and biogeochemical interactions. In: Kristensen E, Haese RR, Kostka JE (eds) Interactions between macro- and microorganisms in marine sediments. AGU, Washington, DC, p 125-158

Kristensen E, Andersen FO, Blackburn TH (1992) Effects of benthic macrofauna and temperature on degradation of macroalgal detritus - the fate of organic-carbon. Limnol Oceanogr 37:1404-1419

Kristensen E, Hansen T, Delefosse M, Banta GT, Quintana CO (2011) Contrasting effects of the polychaetes Marenzelleria viridis and Nereis diversicolor on benthic metabolism and solute transport in sandy coastal sediment. Mar Ecol Prog Ser 425:125-139

> Langezaal AM, Ernst SR, Haese RR, van Bergen PF, van der Zwaan GJ (2003) Disturbance of intertidal sediments: the response of bacteria and foraminifera. Estuar Coast Shelf Sci 58:249-264

> Leppäkoski E, Gollasch S, Gruszka P, Ojaveer H, Olenin S, Panov V (2002) The Baltic - a sea of invaders. Can J Fish Aquat Sci 59:1175-1188

Meier HEM, Andersson HC, Eilola K, Gustafsson BG and others (2011) Hypoxia in future climates: a model ensemble study for the Baltic Sea. Geophys Res Lett 38: L24608, doi:10.1029/2011GL049929

Nielsen LP (1992) Denitrification in sediment determined from nitrogen isotope pairing. FEMS Microbiol Ecol 86: 357-362

Nizzoli D, Welsh DT, Fano EA, Viaroli P (2006) Impact of clam and mussel farming on benthic metabolism and nitrogen cycling, with emphasis on nitrate reduction pathways. Mar Ecol Prog Ser 315:151-165

Nizzoli D, Bartoli M, Cooper M, Welsh DT, Underwood GJC, Viaroli P (2007) Implications for oxygen, nutrient fluxes and denitrification rates during the early stage of sediment colonisation by the polychaete Nereis spp. in four estuaries. Estuar Coast Shelf Sci 75:125-134

- Norkko J, Reed DC, Timmermann K, Norkko A and others (2012) A welcome can of worms? Hypoxia mitigation by an invasive species. Glob Change Biol 18:422-434

$>$ Pelegri SP, Nielsen LP, Blackburn TH (1994) Denitrification in estuarine sediment stimulated by the irrigation activity of the amphipod Corophium volutator. Mar Ecol Prog Ser 105:285-290

Quintana CO, Hansen T, Delefosse M, Banta G, Kristensen E (2011) Burrow ventilation and associated porewater irrigation by the polychaete Marenzelleria viridis. J Exp Mar Biol Ecol 397:179-187

Rabalais NN, Diaz RJ, Levin LA, Turner RE, Gilbert D, Zhang J (2010) Dynamics and distribution of natural and human-caused hypoxia. Biogeosciences 7:585-619

- Racchetti E, Bartoli M, Soana E, Longhi D, Christian RR,
Pinardi M, Viaroli P (2011) Influence of hydrological connectivity of riverine wetlands on nitrogen removal via denitrification. Biogeochemistry 103:335-354

Reed DC, Slomp CP, Gustafsson BG (2011) Sedimentary phosphorus dynamics and the evolution of bottom-water hypoxia: a coupled benthic-pelagic model of a coastal system. Limnol Oceanogr 56:1075-1092

Risgaard-Petersen N, Rysgaard S (1995) Nitrate reduction in sediments and waterlogged soil measured by ${ }^{15} \mathrm{~N}$ techniques. In: Alef K, Nannipieri P (eds) Methods in applied soil microbiology and biochemistry. Academic Press, London, p 287-295

Risgaard-Petersen N, Rysgaard S, Revsbech NP (1995) Combined microdiffusion-hypobromite oxidation method for determining nitrogen-15 isotope in ammonium. Soil Sci Soc Am J 59:1077-1080

Risgaard-Petersen N, Nielsen LP, Rysgaard S, Dalsgaard T, Meyer RL (2003) Application of the isotope pairing technique in sediments where anammox and denitrification coexist. Limnol Oceanogr Methods 1:63-73

Rozan TF, Taillefert M, Trouwborst RE, Glazer BT and others (2002) Iron-sulfur-phosphorus cycling in the sediments of a shallow coastal bay: implications for sediment nutrient release and benthic macroalgal blooms. Limnol Oceanogr 47:1346-1354

Schiedek D (1997) Marenzelleria viridis (Verrill, 1873) (Polychaeta), a new benthic species within European coastal waters. Some metabolic features. J Exp Mar Biol Ecol 211:85-101

Schiffers K, Teal LR, Travis JMJ, Solan M (2011) An open source simulation model for soil and sediment bioturbation. PLoS ONE 6:e28028

Schneider A (1996) Metabolic rate of the brackish water polychaete Marenzelleria viridis under reducing conditions. Thermochim Acta 271:31-40

Stocum ET, Plante CJ (2006) The effect of artificial defaunation on bacterial assemblages of intertidal sediments. J Exp Mar Biol Ecol 337:147-158

Svensson JM (1998) Emission of $\mathrm{N}_{2} \mathrm{O}$, nitrification and denitrification in a eutrophic lake sediment bioturbated by Chironomus plumosus. Aquat Microb Ecol 14:289-299

Svensson JM, Enrich-Prast A, Leonardson L (2001) Nitrification and denitrification in a eutrophic lake sediment bioturbated by oligochaetes. Aquat Microb Ecol 23:177-186

Trimmer M, Risgaard-Petersen N, Nicholls JC, Engstrom P (2006) Direct measurement of anaerobic ammonium oxidation (anammox) and denitrification in intact sediment cores. Mar Ecol Prog Ser 326:37-47

Tuominen L, Makela K, Lehtonen KK, Haahti H, Hietanen S, Kuparinen J (1999) Nutrient fluxes, porewater profiles and denitrification in sediment influenced by algal sedimentation and bioturbation by Monoporeia affinis. Estuar Coast Shelf Sci 49:83-97

Vahtera E, Conley DJ, Gustafsson BG, Kuosa H and others (2007) Internal ecosystem feedbacks enhance nitrogenfixing cyanobacteria blooms and complicate management in the Baltic Sea. Ambio 36:186-194

Zettler ML, Bick A, Bochert R (1995) Distribution and population dynamics of Marenzelleria viridis (Polychaeta, Spionidae) in a coastal water of the southern Baltic. Arch Fish Mar Res 42:209-224

Zettler ML, Daunys D, Kotta J, Bick A (2002) History and success of an invasion into the Baltic Sea: the polychaete Marenzelleria cf. viridis, development and strategies. In: Leppäkoski E, Olenin S, Gollasch S (eds) Invasive aquatic species of Europe, distribution, impacts and management. Kluwer Academic, Dordrecht, p 66-75 
Appendix 1.

Table A1. Main chemical and physical parameters measured in the water flowing from the water tank reservoirs to the box core mesocosms. The water effluent was sampled $1 \mathrm{~d}$ before the first incubation was carried out

\begin{tabular}{|lccccccc|}
\hline $\begin{array}{c}\text { Temperature } \\
\left({ }^{\circ} \mathrm{C}\right)\end{array}$ & $\begin{array}{c}\mathrm{O}_{2} \\
(\mu \mathrm{M})\end{array}$ & $\begin{array}{c}\mathrm{NH}_{4}{ }^{+} \\
(\mu \mathrm{M})\end{array}$ & $\begin{array}{c}\mathrm{NO}_{2}{ }^{-} \\
(\mu \mathrm{M})\end{array}$ & $\begin{array}{c}\mathrm{NO}_{3}{ }^{-} \\
(\mu \mathrm{M})\end{array}$ & $\begin{array}{c}\mathrm{PO}_{4}{ }^{3-} \\
(\mu \mathrm{M})\end{array}$ & $\begin{array}{c}\mathrm{H}_{4} \mathrm{SiO}_{4} \\
(\mu \mathrm{M})\end{array}$ \\
\hline $\begin{array}{l}\text { Normoxic reservoir } \\
5.1\end{array}$ & 312.5 & 2.6 & 0.2 & 2.8 & 0.6 & 17.4 \\
Hypoxic reservoir & 5.1 & 48.4 & 3.4 & 0.6 & 1.0 & 0.5 & 19.4 \\
\hline
\end{tabular}

Table A2. One-way parametric $\left(D_{\mathrm{w}}\right.$ rates and $\mathrm{PO}_{4}{ }^{3-}$ fluxes) and non-parametric (Kruskal-Wallis test, all remaining measurements) analysis of variance for the hypoxic (HY), normoxic (NO) and normoxic-bioturbated (NOB) treatments. Pairwise comparison was performed by means of Tukey test. Letters: significant differences between fluxes; same letter: no significant differences

\begin{tabular}{|llrrrr|}
\hline & Analysis & \multicolumn{1}{c}{$\mathrm{p}$} & $\mathrm{HY}$ & $\mathrm{NO}$ & $\mathrm{NOB}$ \\
\hline $\mathrm{O}_{2}$ flux & $H_{2,33}=29.13$ & $<0.001$ & $\mathrm{a}$ & $\mathrm{b}$ & $\mathrm{c}$ \\
$\mathrm{CH}_{4}$ flux & $H_{2,33}=2.02$ & 0.365 & $\mathrm{a}$ & $\mathrm{a}$ & $\mathrm{a}$ \\
$\mathrm{Mn}^{2+}$ flux & $H_{2,33}=26.02$ & $<0.001$ & $\mathrm{a}$ & $\mathrm{a}$ & $\mathrm{b}$ \\
$\mathrm{Fe}^{2+}$ flux & $H_{2,33}=5.30$ & 0.071 & $\mathrm{a}$ & $\mathrm{a}$ & $\mathrm{a}$ \\
$D_{\mathrm{w}}$ rate & $F_{2,33}=2.84$ & 0.073 & $\mathrm{a}$ & $\mathrm{a}$ & $\mathrm{a}$ \\
$D_{\mathrm{n}}$ rate & $H_{2,33}=31.14$ & $<0.001$ & $\mathrm{a}$ & $\mathrm{b}$ & $\mathrm{c}$ \\
$D_{\text {tot }}$ rate & $H_{2,33}=30.92$ & $<0.001$ & $\mathrm{a}$ & $\mathrm{b}$ & $\mathrm{C}$ \\
$\mathrm{DNRA}_{\mathrm{n}}$ rate & $H_{2,15}=5.43$ & 0.071 & $\mathrm{a}$ & $\mathrm{a}$ & $\mathrm{a}$ \\
$\mathrm{DNRA}_{\mathrm{w}}$ rate & $H_{2,15}=9.87$ & 0.007 & $\mathrm{a}$ & $\mathrm{b}$ & $\mathrm{c}$ \\
$\mathrm{DNRA}_{\text {tot }}$ rate & $H_{2,15}=10.25$ & 0.006 & $\mathrm{a}$ & $\mathrm{b}$ & $\mathrm{c}$ \\
$\mathrm{NH}_{4}{ }^{+}$flux & $H_{2,33}=27.88$ & $<0.001$ & $\mathrm{a}$ & $\mathrm{b}$ & $\mathrm{c}$ \\
$\mathrm{NO}_{3}{ }^{-}$flux & $H_{2,33}=22.11$ & $<0.001$ & $\mathrm{a}$ & $\mathrm{b}$ & $\mathrm{b}$ \\
$\mathrm{PO}_{4}{ }^{3-}$ flux & $F_{2,33}=3.70$ & 0.036 & $\mathrm{a}$ & $\mathrm{a}$ & $\mathrm{b}$ \\
$\mathrm{H}_{4} \mathrm{SiO}_{4}$ flux & $H_{2,33}=13.92$ & $<0.001$ & $\mathrm{a}$ & $\mathrm{b}$ & $\mathrm{a}$ \\
\hline
\end{tabular}

Table A3. Slope of the regression between $p^{29} \mathrm{~N}_{2}$ and $p^{30} \mathrm{~N}_{2}$ and the amount of the added labeled nitrate for the normoxic (NO), normoxic-bioturbated (NOB) and hypoxic (HY) treatments $( \pm \mathrm{SE})$

\begin{tabular}{|c|c|c|c|c|c|c|}
\hline & \multicolumn{2}{|l|}{$-\mathrm{NO}-$} & \multicolumn{2}{|c|}{$\mathrm{NOB}$} & \multicolumn{2}{|l|}{$-\mathrm{HY}-$} \\
\hline & Slope & $\mathrm{p}$ & Slope & $\mathrm{p}$ & Slope & $\mathrm{p}$ \\
\hline $\mathrm{d}\left(p^{29} \mathrm{~N}_{2}\right) / \mathrm{d}\left({ }^{15} \mathrm{NO}_{3}{ }^{-}\right)$ & $0.101 \pm 0.021$ & 0.041 & $0.044 \pm 0.008$ & 0.035 & $-0.013 \pm 0.006$ & 0.175 \\
\hline $\mathrm{d}\left(p^{30} \mathrm{~N}_{2}\right) / \mathrm{d}\left({ }^{15} \mathrm{NO}_{3}^{-}\right)$ & $0.093 \pm 0.005$ & 0.003 & $0.154 \pm 0.006$ & 0.002 & $0.107 \pm 0.050$ & 0.188 \\
\hline
\end{tabular}

Table A4. Results of the analysis of covariance, testing the parallelism of $p^{29} \mathrm{~N}_{2}$ and $p^{30} \mathrm{~N}_{2}$ within the 3 treatments normoxic (NO), normoxic-bioturbated (NOB) and hypoxic (HY)

\begin{tabular}{|c|c|c|c|c|c|c|c|c|c|}
\hline & \multicolumn{3}{|c|}{$\longrightarrow \mathrm{NO}-$} & \multicolumn{3}{|c|}{$-\mathrm{NOB}-$} & \multirow[b]{2}{*}{$\mathrm{df}$} & $-\mathrm{HY}$ & \multirow[b]{2}{*}{$\mathrm{p}$} \\
\hline & $\mathrm{df}$ & $F$ & $\mathrm{p}$ & df & $F$ & $\mathrm{p}$ & & $F$ & \\
\hline Covariate $\left({ }^{15} \mathrm{NO}_{3}{ }^{-}\right)$ & 1 & 72.92 & 0.000 & 1 & 112.54 & 0.000 & 1 & 4.25 & 0.052 \\
\hline Dependent variable $\left(p^{29} \mathrm{~N}_{2}\right.$ and $\left.p^{30} \mathrm{~N}_{2}\right)$ & 1 & 25.92 & 0.000 & 1 & 4.93 & 0.038 & 1 & 23.91 & 0.000 \\
\hline $\begin{array}{l}\text { Interaction between covariate } \\
\text { and dependent variable }\end{array}$ & 1 & 0.12 & 0.735 & 1 & 34.97 & 0.000 & 1 & 6.94 & 0.016 \\
\hline Residuals & 20 & & & 20 & & & 20 & & \\
\hline
\end{tabular}

Editorial responsibility: Martin Solan, Southampton, UK
Submitted: June 6, 2012; Accepted: December 19, 2012

Proofs received from author(s): April 3, 2013 